\title{
Sekularisme og anerkendelse
}

\author{
SIGNE ENGELBRETH LARSEN
}

ENGLISH ABSTRACT: Although religion is an immensely debated subject in the political sphere in Denmark, it remains a frequently stated point of view amongst highly profiled politicians that religious references do not belong in a public debate. From this widespread secularist notion follows a somewhat underestimated mis-recognition of the political and democratic capabilities of religiously influenced people as such. This article further states that mainly Moslem citizens in Denmark suffers from this exclusion due to the fact that the minority position, which they inhabit, makes their religious affiliations stand out more clearly. Following theorists like William E. Connolly, Charles Taylor, Axel Honneth and Nancy Fraser the article thus seeks out to clarify to what extent a democratic society should recognize its religious citizens.

DANSK RESUMÉ: Religion og religiøse problemstillinger diskuteres intensivt $i$ de danske medier, og politikere tager stadigt mere del $i$ denne debat. Ikke desto mindre synes det overordnede politiske budskab stadig at være, at religionen skal holdes ude af det offentlige og politiske rum. I denne artikel argumenteres for, at denne udbredte sekularistiske sondring mellem religion og politik reelt medfører en asymmetrisk positionering af religiøse individer, som afholdes fra at deltage i og præge den offentlige debat på lige vilkår med alle andre borgere. Ved hjælp at teoretikere som William E. Connolly, Charles Taylor, Axel Honneth og Nancy Fraser problematiserer artiklen således sekularismens udgrænsning af religionen, og afsøger i hvilket omfang et demokratisk samfund bør anerkende sine religiøse borgere.

KEYWORDS: Recognition, misrecognition, secularism, multiculturalism, religion and politics, religion in the public sphere 
"Jeg er nødt til at sige det alvorligt, at hois vi skal sikre et Danmark, der hænger sammen i fremtiden, så er vi altså nødt til at holde fast $i$ den danske tradition med, at vi skelner klart mellem politik og religion. Og religion er som udgangspunkt et personligt anliggende og ikke noget vi skal gøre til et samfundsspørgsmål"

- Anders Fogh Rasmussen, Profilen, 16.02.2006.

Ud fra en omfattende undersøgelse af den danske avisdebat kortlagde Kristeligt Dagblad i slutningen af 2007, hvilke personer der i det forgangne år havde domineret religionsdebatten i medierne. Det viste sig, at politikere i langt højere grad end både præster, imamer og religionsvidenskabelige eksperter diskuterede religion i den danske offentlighed - en paradoksal tendens eftersom det gennemgående tværpolitiske budskab ofte er, at religion og politik skal holdes skarpt adskilt (Skov 2007). Som også det indledende citat af Anders Fogh Rasmussen viser, synes det med andre ord mere legitimt at stå i 'den politiske lejr' og tematisere religionen end at stå i 'den religiøse lejr' og ytre sig om politik. Undersøgelsen illustrerer dermed, at den politiske markering af nødvendigheden af at adskille politik og religion kan være med til at skabe en asymmetrisk debatsituation, hvor religiøse borgere vanskeligt kan tage til genmæle over for en vedvarende politisk kritik af religionen.

Den normative politiske udgrænsning af religionen - som jeg i det følgende vil benævne ved hjælp af termen 'sekularisme' - har dermed den faktiske konsekvens, at den implicit sætter spørgsmålstegn ved religiøse menneskers demokratiske manøvredygtighed, dvs. ved deres ret til at deltage i den offentlige debat og dermed præge den fortsatte forhandling af samfundets normer og værdier. I tråd med Ole Wæver vil jeg således skelne mellem begreberne 'sekularisme' og 'sekularisering':

Sekularisering er en samfundsproces, hvor religionens indflydelse på samfundet svækkes. Sekularisme er - en isme, en doktrin for hvordan samfundet bør indrettes. Religion og politik bør adskilles - og beskyttes mod hinanden, for at sikre såvel religionsfrihed som religionsfri politik (Wæver 2004, 2).

Inden for en sekularistisk horisont er det med andre ord nødvendigt at skelne skarpt mellem det private (evt. religiøse) individ og den offentlige borger. I en sådan optik vil de religiøse borgere, som med deres ydre fremtoning eller ytringer henviser eksplicit til deres tro uden for privatsfæren, dermed ofte ikke blive anerkendt som legitime aktører i en offentlig debat. Det er netop denne manglende anerkendelse, som nærværende artikel vil undersøge og problematisere.

Dette vil jeg gøre ved først at godtgøre eksistensen af en sekularistisk position i Danmark, hvor jeg vil tage afsæt i debatten om Enhedslistens folketingskandidat Asmaa 
Abdol-Hamid. Efterfølgende vil den sekularistiske position blive problematiseret under inddragelse af William E. Connolly samt Jeff Spinner-Halev og José Casanova. I artiklens anden del vil jeg i forsøget på at overskride et rent kritisk perspektiv undersøge, på hvilken måde nyere teorier om begrebet 'anerkendelse' (eks. Charles Taylors, Axel Honneths og Nancy Frasers) kan bruges til at komme ud over den normative sekularismes negative konsekvenser i forhold til skabelsen af en inkluderende og demokratisk offentlighed. Målet er således for det første at beskrive, hvorfor det overhovedet er relevant at tale om et aktuelt behov for anerkendelse af religiøse borgere i den danske samtidskultur, og for det andet at diskutere, hvad en sådan anerkendelse rent faktisk indebærer.

\section{Sekularismen og dens kritikere}

I forbindelse med det danske folketingsvalg i 2007 rejste der sig en massiv sekularistisk funderet kritik af den kvindelige muslim Asmaa Abdol-Hamid. Abdol-Hamids folketingskandidatur for Enhedslisten mødte modstand fra flere sider, særligt fordi hun bærer tørklæde og af religiøse årsager ikke ønsker at give hånd til mænd. Mogens Camre (MEP) fra Dansk Folkeparti slog på den baggrund fast, at det "er en syg idé og helt naturstridigt, at en fundamentalist med tørklæde skal være medlem af vores demokratiske parlament" (Brix \& Lund 2007). Kritikken fra Enhedslistens eget bagland var dog også markant. Tidligere MF'ere som Kjeld Albrechtsen og Bent Hindrup deltog som eksempel i Enhedslistens 'religionskritiske netværk' oprettet i protest mod AbdolHamids opstilling. I netværkets arbejdsgrundlag hedder det bl.a.: “Der findes i Enhedslisten stærke kræfter, som mener, at religionen kan spille en positiv rolle, og at partiet må åbne sig for mennesker, der åbent vedkender sig en religiøs overbevisning. Denne tendens vender vi os imod" (Bendix Olsen \& Hoffmann-Hansen 2007). Både Hindrup og Albrechtsen mente således ikke, at Abdol-Hamid kunne tale som repræsentant for Enhedslisten fra Folketingets talerstol, fordi hun i kraft af sit tørklæde 'skiltede' med sin religion. Som Albrechtsen selv formulerede det til Jyllands-Postens netavis: "Folk må gerne have en religion, men ikke skilte med den politisk. Trosfriheden må gælde helt op på Folketingets talerstol. Men retten til at udbrede sin tro stopper ved trappetrinnet" (Justesen 2007). Abdol-Hamids synlige religiøsitet gjorde hende ifølge denne logik ganske simpelt uegnet til at varetage hvervet som folkevalgt politiker. For Albrechtsen vil Abdol-Hamid således altid allerede være missionerende qua sit religiøst konnoterede tørklæde.

Sekularismen hører dog ikke kun til på de alleryderste politiske fløje. SFs formand Villy Søvndal udtrykte en lignende pointe i forbindelse med den ophedede debat om mordet på den hollandske filminstruktør Theo van Gogh: "[D]et religiøse er noget privat. Når vi færdes på offentlig vej eller skriver i avisen - så er vi borgere" (Søvndal 2005). Ifølge Søvndal er 'borgere' - dvs. deltagere i den offentlige og politiske debat - altså religiøst neutrale, og dermed udelukkes indirekte mennesker med en meget 
eksplicit religiøs overbevisning. Statsminister Anders Fogh Rasmussen kan tjene som et andet eksempel. Fogh Rasmussen har gentagne gange skabt debat ved sine klare udmeldinger om, at religionen bør holdes i privatsfæren. I statsministerens Grundlovstale fra 2006 hedder det: "Det er farligt, når personlig tro bliver erstattet af en lovreligion, hvor det enkelte menneske skal underordne sig årtusinde gamle forskrifter. Og samfundet indrette sig efter religiøse påbud. I Danmark skelner vi mellem politik og religion" (Hoffmann-Hansen 2006). I denne udtalelse udmærker statsministeren endvidere den personlige tro frem for lovreligionen, og han laver dermed reelt en utvetydig privilegering af den kristen-protestantiske religion på bekostning af lovreligioner som jødedommen og islam. Sidst, men ikke mindst, kan nævnes statsministerens partifælle beskæftigelsesminister Claus Hjort Frederiksen, der formulerede sig således i sin Grundlovstale i 2007:

Jeg respekterer andres religion. Og jeg kæmper dagligt for den grundlovssikrede religionsfrihed. Men religion er en privat sag, som ikke skal fylde i det offentlige rum. Det ødelægger sammenhængskraften og harmonien i det danske samfund. Det underminerer det danske frisind. Og det rykker ved den meget høje grad af gensidig tillid, vi har til hinanden i Danmark (Hjorth-Frederiksen 2007).

Både Statsministeren og Hjorth-Frederiksen udpeger altså den offentlige religion til at være en trussel mod selve sammenhængskraften i samfundet, og ifølge beskæftigelsesministeren underminerer en synlig religion desuden den grundlæggende tillid mellem borgerne.

Som citaterne viser, er den sekularistiske fordring om et religionsfrit offentligt rum - samt forestillingen om religionen som en trussel mod den demokratiske samfundsopbygning - altså ikke bundet til særlige politiske positioner, men tværtimod en bredere strømning, der går på tværs af det politiske spektrum. Det er klart, at modstanden mod den offentlige religion ikke kommer til udtryk på samme måde i Dansk Folkeparti, Venstre, SF og Enhedslisten. Nogle af de nævnte politikere er eksempelvis meget imod tørklædet, mens andre ikke finder det problematisk i sig selv. Trods disse variationer er det dog kendetegnende, at man overordnet set modsætter sig den religiøse prægning af det offentlige rum og den politiske debat.

\subsection{Religionen og det offentlige rum}

Sekularismens grundliggende ambition er at presse religionen ind i privatsfæren, dvs. gøre den til et personligt anliggende uden politiske konsekvenser, hvilket bl.a. bygger på en frygt for religionen som en kilde til splid eller kulturelle antagonismer. Jeff Spinner-Halev beskæftiger sig i bogen Surviving Diversity: Religion and Democratic Citizenship (2000) netop specifikt med frygten for den 'politiske religion', som ofte aktiveres, når institutioner og individer kommer med religiøse referencer i offentlige debat- 
ter. Denne skepsis kan if. Spinner-Halev primært siges at have rod i to udbredte forestillinger (Spinner-Halev 2000, 142f). Den første er, at debatter, som udspringer af og handler om religiøse emner, uvægerligt vil grave uoverskridelige grøfter mellem de involverede befolkningsgrupper. Den anden forestilling er, at det er udemokratisk overhovedet at fremføre et religiøst argument i en offentlig debat, fordi man ved at henvise til noget guddommeligt forsøger at påtvinge andre mennesker sin egen subjektive sandhed. Hvad angår førstnævnte indvending mod religion i det offentlige rum påpeger Spinner-Halev dog, at religiøse mennesker på ingen måde har patent på at være lidenskabelige eller polariserende debattører, hvilket understreges af, at de politiske ideologier må siges at have mindst lige så megen splittelse (og krigsførelse) på samvittigheden som religionen. I relation til den anden indvending har Ole Wæver i en dansk kontekst påpeget, at det langt fra er kendetegnende for den almene debat, at alle andre argumenter er 'hyperrationelle' eller renset for subjektivitet: "Dette viser, at vi ikke har at gøre med en almen høj standard, som tros-argumenter ikke lever op til - vi har at gøre med et særforbud mod religiøse begrundelser i dansk politik" (Wæver 2004, 7). Det er således Wævers anke, at sekularismen foregiver at udstikke neutrale retningslinier for det offentlige rum, mens den i virkeligheden forfordeler en specifik samfundsgruppe. Også religionsforsker Tim Jensen har problematiseret de politiske udmeldinger om at holde religionen ude af den politiske sfære. Hans pointe er, at religion og politik allerede er sammenvævet på flere måder:

Imamer, der opfordrer folk til at stemme på bestemte politiske partier, bliver skældt ud af Khader, Fogh og Haarder. Sådan gør man ikke i DK, for her har vi en luthersk-protestantisk ordning, der hævder at adskille religion og politik, samtidig med at den kristne gud alligevel står over det hele som første og sidste instans. Vi har en statskirke, en kirkeminister, der er præst (men det er hun selvfølgelig ikke, mens hun er minister), en minister, der går ind i kirkens forhold (f.eks. Grosbøll-sagen), en grundlov, der sikrer politisk (stats)støtte til kirken, adskillige præster, der er politikere og omvendt, flere politikere, der bekender, at de er kristne og arbejder på at udgå i deres politiske virke fra deres kristne overbevisning [...] (Jensen 2005).

I forlængelse af statsministerens valorisering mellem den personlige tro og lovreligionen anfører Jensen dermed, at den sekularistiske fordring om at holde politik og religion adskilt, kan komme til at virke diskriminerende, fordi den ofte bruges til at holde minoritære religiøse positioner ude af debatten, mens majoriteten selv ofte og ganske udramatisk overskrider denne grænse. Den offentlige debat er således i forvejen præget af en mangfoldighed af modsatrettede standpunkter, idet mange interessegrupper kritiserer samfundet i forskellige henseender og ud fra forskellige værdisæt (jf. Parekh 2002, 328f). Det kan med andre ord synes svært at retfærdiggøre, hvorfor netop religiøse mennesker ikke med samme ret kan bruge deres argumenter til at bidrage til en konstruktiv forhandling af samfundets indretning (Casanova 1994, 43). 


\subsection{Sekularisme og protestantisme}

Det er ifølge både Spinner-Halev, Wæver og Jensen derfor snarere udelukkelsen af de religiøse argumenter fra debatten, der skaber unødig samfundsmæssig splittelse. Det sekularistiske krav om en klar adskillelse af det personlige og det offentlige/politiske individ skaber således - som i tilfældet med Asmaa Abdol-Hamid - reelt en barriere for eksempelvis praktiserende muslimers politiske deltagelsesmuligheder, idet de forventes at tilsidesætte væsentlige dele af deres fundamentale værdigrundlag for at blive accepteret som legitime aktører i det offentlige rum (jf. Parekh 2002, 322f). Dette er dog med Spinner-Halev en både urimelig og umulig fordring:

\footnotetext{
If religious people speak in public using the language of secular reason they must be able to see the world through secular and sacred eyes. But religion informs the worldview of many religious people. They cannot look at issues only through a secular lens, since doing so means denying their religious views, something that is impossible for many religious people to do. Certainly religious liberty means being able to act on one's beliefs. It would be peculiar to say that this is true in private but not in public; such an argument presumes a neat division between public and private that does not exist (Spinner-Halev 2000, 146).
}

I forlængelse af denne kritik af sekularismen som en mulig barriere for demokratisk debat må det samtidig fastholdes, at den sekularistiske sondring mellem den private religion og den politiske offentlighed ikke er en kulturneutral fordring, der rammer alle religioner på samme måde. Det er således værd at holde for øje, at sekularismen er særdeles tæt forbundet med den kristne protestantisme (jf. bl.a. Connolly 1999, 1929; Casanova 1994, 214; Taylor 1992, 62), dvs. den understøtter og harmonerer i udpræget grad med en kristen-protestantisk opfattelse af religionen som en privat sag mellem Gud og hin enkelte. Dette forklarer, hvorfor sekularismen kan virke naturlig, frisættende og selvindlysende i en sekulariseret kristen-protestantisk kulturtradition, mens den i en anden religiøs optik kan virke diskriminerende og begrænsende. At det offentlige rum bør holdes religiøst neutralt, fremstår og fremføres således ofte som en upartisk fordring eller en neutral spilleregel, men denne fordring tager ikke hensyn til de religioner som - i modsætning til kristendommen - kræver af sine tilhængere, at de ihukommer deres tro ved mere offentlige handlinger som eksempelvis daglige bønner, særlige spiseregler eller religiøst konnoterede beklædningsgenstande, der vel at mærke ikke kun skal bæres inden for hjemmets fire vægge. Normen om den privatiserede tro afspejler således en specifik liberal, protestantisk, vesteuropæisk historie og samfundstradition. Samme norm ville følgelig ikke være 'naturlig' eller indlysende i samme grad i eksempelvis et islamisk samfund, der har integreret religionen i det offentlige liv eller i samfund, der tager højde for en religiøs pluralisme i befolkningen (jf. Casanova 1994, 214; Jensen 2003, 28). 
I Why I am not a secularist (1999) argumenterer William E. Connolly som alternativ for en mere inkluderende offentlighedsmodel, der undgår den konfliktmotiverende eksklusion af religiøse motiver (Connolly 1999, 39). Begrebet 'the politics of becoming' danner det centrale omdrejningspunkt for Connollys teori, der baseres på et kultur- og identitetssyn præget af vedvarende forhandling og forandring (Connolly 1999, 57f). Den dynamiske og konstruktive proces, som konstant omskaber individet og dets relationer, hæmmes dog if. Connolly netop af en sekularisme, der begrænser individets ageren og fremtræden i det offentlige rum. Connolly plæderer således i stedet for en 'multidimensionel pluralisme':

Public culture inside and outside the state is now constituted by multiple minorities, divided along more numerous lines of religion, linguistic habit, economic interest, irreligion, ethnicity, sensuality, gender performances, and moral sources of inspiration than Mill felt compelled to acknowledge. These constituencies share overlapping commitments to each other and to a set of procedures, but this sharing now takes the form of general ethos negotiated between constituencies honouring a variety of moral sources. This is the overlapping consensus of John Rawls reworked. For here, partisans bring selective dimensions of their religious, ethnic, sensual, gender, and moral sensibilities into public engagements whenever the issue makes it pertinent to do so (Connolly 1999, 92).

For Connolly bør samfundets ethos, dvs. dens fælles moralske og værdimæssige orienteringsramme, altså kunne forhandles mellem eksempelvis forskellige religiøse og sekulære overbevisninger. Som et nærliggende eksempel på denne 'overlapping consensus' kan nævnes nedenstående udtalelse af Asmaa Abdol-Hamid, der i et interview i Nyhedsavisen blev spurgt, hvorfor Danmark i hendes øjne er 'et islamisk land':

Fordi vi har frihedsrettigheder, menneskerettigheder og et velfærdssamfund. Princippet om omfordeling af ydelser er hentet fra islam. Skattesystemet er islamisk. Når jeg ser på forholdene mange steder i Mellemøsten, kan jeg ikke se islam, men diktatur og undertrykkelse. I Syrien er ytringsfrihed og religionsfrihed undergravet. Det er uislamisk (Bock 2007).

Udtalelsen illustrerer Connollys pointe; at man godt kan forhandle sig frem til fælles værdier og spilleregler uden at motivkontrollere deltagerne i den offentlige debat. Med en sådan multidimensional pluralisme forhindres det endvidere ifølge Connolly, at en specifik moralsk, religiøs eller politisk overbevisning tager patent på samfundets værdigrundlag, samtidig med at det anerkendes, at borgere, der ikke sondrer mellem en privat og en offentlig identitet, også kan indgå som forhandlende og demokratiske samfundsaktører. 


\section{Religion og anerkendelse}

Connolly kan på sin vis siges at mediere mellem en multikulturalistisk tradition og den såkaldte anerkendelsesfilosofi. Bhikhu Parekh, Tariq Modood, Iris Marion Young og Will Kymlicka er nogle af de fremtrædende teoretikere inden for multikulturalismen, og deres værker har på forskellig vis forsøgt at reflektere over muligheden for en større inklusion af etniske og kulturelle mindretal i de vestlige samfund. ${ }^{1}$ Med Connolly indebærer respekten for individet som demokratisk aktør således også en grundlæggende anerkendelse af vedkommendes kulturelle og religiøse baggrund. I nærværende sammenhæng er det min påstand, at anerkendelsesbegrebet netop kan være en konstruktiv indgang til diskussionen af religionens plads i det offentlige rum. I det følgende gives derfor en kortere præsentation og problematisering af nogle nyere overvejelser omkring anerkendelsesbegrebet og ikke mindst dets relevans i forhold til en overskridelse af sekularismens udsondring af den religiøse borger.

I 1992 udkom Charles Taylors berømte essay “The Politics of Recognition". Taylor identificerede her begrebet anerkendelse som et afgørende og fundamentalt omdrejningspunkt for en multikulturalistisk teoridannelse. Anerkendelse skal i denne sammenhæng forstås som en skabende aktivitet, der også former den anerkendtes selvbillede, og derfor er anerkendelsen ikke bare "a courtesy we owe people. It is a vital human need" (Taylor 1994, 26). I samfund præget af kulturel pluralisme er anerkendelsen central, fordi den er med til at forme borgernes oplevelse af at være et ligeværdigt individ. Den manglende anerkendelse vil følgelig være problematisk, fordi den reelt udgør en art underkendelse af visse individers kulturelle legitimitet:

The thesis is that our identity is partly shaped by recognition or its absence, often by the misrecognition of others, and so a person or a group of people can suffer real damage, real distortion, if the people or society around them mirror back to them a confining or demeaning or contemptible picture of themselves. Nonrecognition or misrecognition can inflict harm, can be a form of oppression, imprisoning someone in a false, distorted, and reduced mode of being (Taylor 1994, 25).

Anerkendelsen er if. Taylor en del af demokratiets fundament, eftersom anerkendelsen af alle borgeres fundamentale ligeværdighed er selve grundtanken i denne styreform. Egentlig anerkendelse fordrer dog if. Taylor, at man i anerkendelsen transcenderer det fælles menneskelige, dvs. at det er det enkelte individ og vedkommendes særlige baggrund - forskellig fra alle andre - som anerkendes i sin egen autenticitet. I sin indkredsning af begrebet 'authenticity' trækker Taylor på bl.a. J. G. Herders forestilling om det enkelte menneske som bærer af en specifik kultur og historie, der er forskellig fra andre kulturer og historier. På den måde forvandles anerkendelsen i Taylors optik

1 Jf. Bhikhu Parekh: Rethinking Multiculturalism (2000), Iris Marion Young: Justice and the politics of difference (1990), Will Kymlicka: Multicultural Citizenship (1995) og Tariq Modood: Multicultural Politics (2005). 
dog faktisk fra at være en anerkendelse af individet som individ, til reelt at være en anerkendelse af individet som del af en anerkendelsesværdig kultur. Det ender med andre ord med at være kulturen og ikke individet, der sættes i centrum. Selvom Taylor er åben for, at denne kulturelle autenticitet er til konstant genforhandling, er det således et problematisk og ofte kritiseret træk ved hans teori, at den relaterer anerkendelsesbegrebet til forestillingen om 'den genuine kultur'. Eksempelvis opererer Taylor med begrebet 'kulturelle rettigheder', hvilket for alvor risikerer at begrænse individets frihed både inden for og uden for en given kulturel formation.

\subsection{Kampen om anerkendelse}

Som et mere dynamisk alternativ til Taylors kulturalistiske anerkendelsesteori kan nævnes Axel Honneth, der betragter anerkendelsen som et kampbegreb, som indgår i sociale aktørers forsøg på at overskride oplevelsen af samfundsmæssig udelukkelse. Et afgørende led i jegets identitetskonstruktion er således afkodningen af 'den andens' eller 'de andres' opfattelse af jeget, dvs. den enkeltes spejling af sig selv i de andres blik. Hvis man her møder foragt eller fordomme, skabes der imidlertid en for individet ubehagelig vaklen mellem, hvad man med Tariq Modood kunne kalde, 'mode of being' og 'mode of oppression', dvs. ens selvforståelse vs. de stigmatiserende identitetsmæssige træk man tillægges af andre. Inspireret af bl.a. George Herbert Meads socialpsykologi understreger Honneth dog, at individet ikke er hjælpeløst bundet af sine omgivelsers accept eller mangel på samme. Individet kan således konfrontere den manglende rummelighed i samfundet ved at kæmpe for at udvide rammerne for den samfundsmæssige anerkendelse (Honneth 2006, 115-119).

Denne stræben betegner Honneth som en 'kamp om anerkendelse', der foregår på tre forskellige niveauer. A) I individets primærrelationer (dvs. kærlighedsforhold og venskaber), hvor den attråede anerkendelse kan karakteriseres som følelsesmæssig opmærksomhed. B) I retslige forhold, hvor anerkendelsen viser sig i form af kognitiv respekt, hvilket udmønter sig $\mathrm{i}$ at individet tilkendes almene rettigheder qua sin position som frit og moralsk kapabelt menneske. C) I det sociale værdifællesskab, hvor anerkendelsen kommer til udtryk som en værdsættelse af individets personlige egenskaber, udmærkelser og bedrifter (Honneth 2006, 174).

Det væsentlige fokusområde er i nærværende sammenhæng feltet mellem den retslige anerkendelse og den sociale værdsættelse. I den retslige sammenhæng anerkendes mennesket for noget generelt, dvs. egentlig for sin blotte menneskelighed, om man vil, mens den sociale værdsættelse beror på en individuel vurdering af kompatibiliteten mellem individets særlige egenskaber og samfundets værdier, normer og behov, altså samfundets generelle orienteringsramme (Honneth 2006, 153f; 164). Det er Honneths pointe, at denne orienteringsramme uvægerligt vil afspejle bestemte sociale gruppers subjektive værdier og livsformer, og dermed reelt underkende andre: 
Den sociale værdsættelse er i de moderne samfund underlagt en permanent kamp, hvor de forskellige grupper ved hjælp af symboler som magtmiddel og under henvisning til de almene målsætninger forsøger at fremhæve værdien af deres egen livsform. Den altid kun midlertidigt stabile udgang af denne kamp afgøres ikke kun af den gruppespecifikke rådighed over det symbolske magtmiddel, men også af den vanskeligt påvirkelige offentlige opmærksomhed. Jo mere markant en social bevægelse formår at gøre opmærksom på sine kollektive egenskabers og muligheders oversete betydning, desto større er dens chance for at fremhæve sine medlemmers sociale værdi, eller netop deres anseelse (Honneth 2006, 170).

If. Honneth er kampen om indholdsbestemmelsen af orienteringsrammen altså vedvarende, men det er helt afgørende, at samfundet som sådan - uagtet denne stadige værdikamp - bindes sammen af en overordnet og gensidig solidaritet mellem borgerne. Solidariteten består i, at alle borgere - i deres fælles interesse - tilstræber et samfund, der er pluralistisk nok til at rumme værdier og livsformer, som er forskellige fra deres egne. Honneth taler her om en samfundsmæssig symmetrisk værdsættelse i den betydning, at "ethvert subjekt, uden et kollektivt hierarki, dvs. i kraft af sine egne præstationer og evner, får chancen for at føle sig værdifuldt for samfundet" (Honneth 2006, 173). Med denne basale (selv)værdsættelse intakt sikres således et stabilt og retfærdigt grundlag for individernes fortsatte kamp om social prestige.

Når en sådan samfundsmæssig solidaritet derimod er brudt, eller slet og ret ikkeeksisterende, kan visse grupper derfor opleve, at deres forventning om anerkendelse, dvs. social værdsættelse, skuffes, fordi deres konkrete egenskaber direkte ringeagtes eller nedvurderes:

Nedvurderingen af bestemte selvrealiseringsformer medfører for de pågældende personer, at de ikke kan sætte deres måde at leve på i forbindelse med noget, der inden for deres fællesskab har en positiv betydning. Erfaringen af denne sociale nedvurdering medfører derfor også, at man ikke har mulighed for personlig selvværdsættelse, dvs. at kunne forstå sig selv som én, der værdsættes for sine karakteristiske egenskaber og muligheder (Honneth 2006, 179).

I forlængelse af ovenstående kan man sige, at det kan være svært for religiøse mennesker at føle sig værdsatte i et samfund, der i udtalt grad er præget af sekularisme. Religiøse individer vil her uvægerligt blive opfattet som antitetiske i forhold til en væsentlig del af den gældende samfundsmæssige orienteringsramme. Erfaringen bibringer if. Honneth desuden det ikke-anerkendte subjekt en smertelig erkendelse af at være fortabt uden sine omgivelsers fundamentale anerkendelse. Det er dog samtidigt denne øjeblikkelige handlingslammelse og fortabthed, som individet med Honneth kan bruge som afsæt for sin politiske kamp for anerkendelse, og det er denne sociale kamp - motiveret af en grundlæggende ringeagtserfaring - som driver samfundsudviklingen frem mod stadig større rummelighed. Udviklingen fra individets moralske 
indignation til mobiliseringen af en kollektiv social kamp foregår således ved, at specifikke ringeagtserfaringer danner rammen for et politisk fællesskab, som motiveres af håbet om fremtidig anerkendelse (Honneth 2006, 208f).

For Honneth er samfundsudvikling og identitetsfrisættelse således to sider af samme sag. Når subjektet ikke kan rummes af det givne samfund, udvikler det sig ved at spejle sig selv og søge anerkendelse i et fremtidigt samfunds blik:

Det eneste subjekterne kan gøre i deres forsvar for deres spontant oplevede krav, er hele tiden at sikre sig accept fra et kontrafaktisk formodet fællesskab, der i forhold til det etablerede anerkendelsesforhold vil tillade dem flere frihedsrettigheder. Det er mængden af sådanne moralske afvigelser - der så at sige hele tiden lægger et net af normative idealer ned over den sociale livsproces -, som er drivkraften i samfundsudviklingen (Honneth 2006, 117).

Honneths grundlæggende udviklingsoptimisme er besnærende, men kan dog kritiseres for ikke i tilstrækkelig grad at tage højde for, at udviklingen af et mere rummeligt samfund altid kræver aktiv deltagelse og billigelse fra majoriteten for at kunne lykkes. Det er med andre ord eksempelvis ikke nok, at 200.000 muslimer i Danmark ønsker et offentlig rum, der er mindre ekskluderende over for religiøse mennesker og tanker, især ikke når dette synspunkt i høj grad italesættes som antitesen til den gældende - og for mange helt ideelle - samfundsstruktur. Det andet problem i nærværende sammenhæng er, at eksempelvis danske muslimer netop ikke er en samlet enhed, men en gruppe præget af så stor indre diversitet, at man reelt ikke kan tale om dem en bloc. Der er således slet ikke et samlet krav om anerkendelse fra denne minoritetsgruppe, der tæller både sekularistiske kulturmuslimer, moderate og stærkt troende med vidt forskellig etnisk, social og uddannelsesmæssig baggrund. Ønsket om anerkendelse af den religiøse livsanskuelse og ønsket om retten til at markere dette livssyn i det offentlige rum opretholdes således af en meget minoritær position præget af indre splittelse, der står i direkte opposition til flertallet, og som derfor vanskeligt kan mobilisere en større politisk bevægelse.

\subsection{Anerkendelse i et statusperspektiv}

Honneths anerkendelsesteori er overordnet set præget af en stor indsigt $\mathrm{i}$ anerkendelsens psykologiske nødvendighed i de intime relationer, men mens den kognitive respekt, der ligger til grund for retssystemets anerkendende ligebehandling, kræver en omhyggelig om end relativt håndgribelig samfundsmæssig indsats, kan det umiddelbart synes svært at implementere en egentlig 'institutionaliseret anerkendelse' i samfundets sociale værdifællesskab. For kan man med rimelighed forlange af et samfund, at det positivt skal værdsætte de kulturelle karakteristika, som den enkelte borger måtte have? Eller kan man i virkeligheden kun kræve, at samfundet ikke på forhånd 
devaluerer eller afskriver et individ på baggrund af dets kulturelle tilhørsforhold? Hvis det sidste er tilfældet, drejer problemstillingen sig måske i virkeligheden mere om at undgå underkendelse end om positiv anerkendelse.

I forlængelse af ovenstående pointe kan man med den amerikanske feminist og kritiske teoretiker Nancy Fraser forsøge at dreje spørgsmålet om anerkendelse væk fra den psykologiske og identitetspolitiske ramme, som præger både Taylors og Honneths analyser. I overensstemmelse med Connollys 'politics of becoming' advarer Fraser således bl.a. imod tendenser til at bruge anerkendelsesbegrebet til at fastfryse kulturelle kategorier på bekostning af individets ret til at gå i dialog med en given kulturel baggrund. I stedet forsøger Fraser at gøre anerkendelsen til et spørgsmål om social status. I 'Rethinking Recognition' hedder det:

\footnotetext{
From this perspective, misrecognition is neither a psychic deformation nor a free-standing cultural harm but an institutionalized relation of social subordination. To be misrecognized, accordingly, is not simply to be thought ill of, looked down upon or devalued in others' attitudes, beliefs or representations. It is rather to be denied the status of a full partner in social interaction, as a consequence of institutionalised patterns of cultural value that constitute one as comparatively unworthy of respect or esteem (Fraser 2000, 113f).
}

For Fraser er man altså anerkendt, når man opfattes som "a full partner in social interaction". I forlængelse af dette perspektiv kan et samfund underkende et individ på forskellig vis enten gennem juridisk forskelsbehandling af visse borgere eller gennem politiske beslutninger, der uforvarende eller bevidst ekskluderer visse individer. Endeligt kan nogle borgere opleve diskrimination, underkendelse eller, hvad Iris Marion Young kalder 'structural oppression', som følge af skikke, fordomme eller vaneantagelser $\mathrm{i}$ et givent samfund, der ikke vil eller formår at anerkende eksempelvis dets indre kulturelle eller religiøse mangfoldighed (jf. Young 1990, 41). Disse former for underkendelse kan dog if. Fraser netop alle modsvares af et legitimt krav om anerkendelse:

But note precisely what this means: aimed not at valorizing group identity but rather at overcoming subordination, in this approach claims for recognition seek to establish the subordinated party as a full partner in social life, able to interact with others as peer (Fraser 2000, 114)

Anerkendelse er således reelt et spørgsmål om at udligne en uretfærdigt akkrediteret lavstatus, og dermed ikke et spørgsmål om at fremhæve visse kulturelle tilhørsforhold som værende særligt anerkendelsesværdige (jf. Taylor). I forlængelse af Frasers statusorienterede analyse handler anerkendelse af religiøse mennesker altså ikke om, at alle borgere i et samfund skal se på verden med religiøse briller, eller om at alt skal være tilladt i religionens navn. Det handler heller ikke om, at alle skal synes, at det religiøse verdensbillede virker tillokkende eller nødvendigvis giver særlig god mening. Aner- 
kendelse af religiøse mennesker handler derimod om at udligne tilløb til asymmetrier, der giver visse individer ringere mulighed for at agere som fuldgyldige medlemmer af det demokratiske samfund, dvs. virker hæmmende i forhold til deres varetagelse af offentlige hverv eller deres ret til at deltage i og præge den fortsatte offentlige meningsudveksling om samfundets værdimæssige orienteringsramme.

Jeg vil med andre ord tilslutte mig Nancy Frasers indirekte pointering af, at anerkendelsesbegrebet er mest konstruktivt, når det bruges til at påpege og modvirke tilløb til underkendelse af visse borgeres demokratiske legitimitet. Fraser formulerer det således: "Redressing misrecognition now means changing social institutions - or, more specifically, changing the interaction-regulating values that impede parity of participation at all relevant institutional sites." (Fraser 2000, 115). Den sekularistiske fordring om, at religiøse motivationer skal holdes ude af politik er netop en sådan 'interactionregulating value'. Med en fremherskende sekularisme risikerer den demokratiske offentlighed derfor reelt at lukke sig om sig selv og blive hegemonisk og statisk frem for pluralistisk og dynamisk i Connollysk forstand.

\section{Konklusion}

Mens anerkendelse er afgørende for individets intime relationer, kan denne vanskeligt institutionaliseres og gøres til et krav om social værdsættelse uden at binde anerkendelsen til specifikke kulturelle kategorier og dermed skabe en problematisk essentialisering af disse kategorier. Den eneste anerkendelse, man som religiøst individ kan gøre krav på i det offentlige rum, er således, at man ikke stilles ringere end andre borgere qua sit religiøse eller kulturelle tilhørsforhold. Dvs. at samfundet, lovgiverne, arbejdsgivere og det sociale værdifællesskab ikke på forhånd - som sekularismens fortalere - afskriver visse borgere eller standpunkter som apriorisk uintegrerbare i den demokratiske offentlighed.

For at imødegå tendenser til underkendelse, må man altså tilstræbe at skabe en kulturel orienteringsramme, hvor det bliver muligt for eksempelvis praktiserende muslimer i Danmark at agere som fuldgyldige demokratiske borgere i det offentlige rum. Inklusionen af religiøse minoriteter i det danske samfund kræver således først og fremmest, at samfundets værdigrundlag ikke i sig selv underkender religiøse menneskers fuldt legitime livsformer og anskuelser. Det offentlige rum bør netop være base for en konstruktiv og multidimensionel pluralisme, som Connolly argumenterer for, og tilbyde en platform, hvorfra alle borger har ret til at ytre og afprøve deres argumenter og visioner.

Det må i forlængelse heraf være en given ytrings argumentative kvalitet eller rimelighed, og ikke en analyse af, hvorvidt dens motiv er verdsligt eller ej, der må være bestemmende for ytringens gennemslagskraft og indvirkning på de demokratiske beslutningsprocesser. Der gives med andre ord ikke en neutral formel for, hvordan man skal udtrykke eller klæde sig for at kunne agere i den politiske sfære; selve forestil- 
lingen om en sådan neutralitet kan endda være med til at standse debatten, fordi den ofte bruges til at adskille de 'samtalende' borgere fra, hvad man kunne kalde de 'monologiske' borgere. Sekularismens rigide opdeling af det private og det offentlige ekskluderer dog netop per definition religiøse mennesker fra demokratiets vigtigste scene, den politiske offentlighed. I stedet for at opstille regler for, hvem der må tale, og hvem der bør tie, vil det derfor være gavnligt at værne om den åbne samfundsforhandling mellem landets borgere og dermed om muligheden for at skabe en konstruktiv dialog også mellem sekulært funderede og religiøse diskurser. Anerkendelse af religiøse individer og religiøse motivationer handler således dybest set ikke om særrettigheder, men om ligestilling.

\section{LITTERATUR}

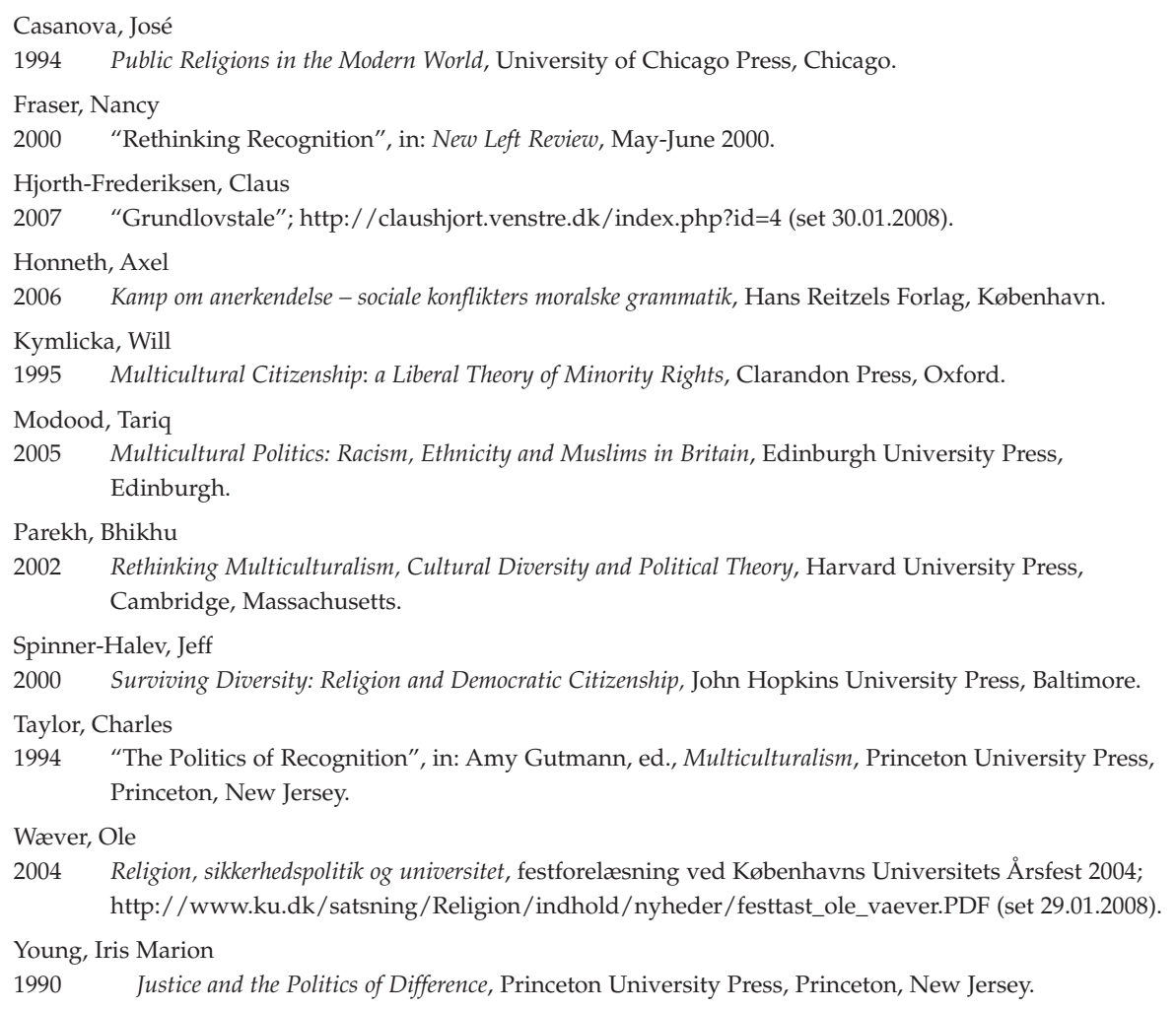

\section{AVISARTIKLER}

Bendix Olsen, Maria \& Hoffmann-Hansen, Henrik

2007 "Netværk siger nej til Asmaa", in: Kristeligt Dagblad, 12.09. 
Bock, Silke

2007 "Danmark er et islamisk land", in: Nyhedsavisen, 20.04.

Brix, Knud \& Lund, Michael

2007 “DF: Alle muslimske samfund er tabersamfund", in: Nyhedsavisen, 20.04.

Hoffmann-Hansen, Henrik

2006 "Religionen i det liberale rum", in: Kristeligt Dagblad, 22.06.

Jensen, Tim

2005 "Det religiøse hykleri slår alle rekorder", in: Kristeligt Dagblad, 02.02.

Justesen, Martin

2007 “Enhedslisten: Asmaa sikker indtil foråret", in: Politiken, 24.09.

Skov, Freya

2007 "Politikerne erobrede religionsdebatten i 2007", in: Kristeligt Dagblad, 27.12.

Søvndal, Villy

2005 "Muhammeds ansigt: alt er til debat for borgere", in: Jyllands-Posten, 25.10.

\section{TV-UDSENDELSER}

DR

2006 Profilen med Anders Fogh Rasmussen 15.02;

http://dr.dk/DR1/Profilen/Udsendelser/2006/02/14173925.htm (set 29.01.2008).

Signe Engelbreth Larsen, ph.d.-stipendiat Institut for Tværkulturelle og Regionale Studier, Københavns Universitet 